\title{
Study on Career-oriented Preschool Project Teaching of Vocational English
}

\author{
Song $\mathrm{GaO}^{1, \text { a }}$ \\ ${ }^{1}$ Panjin Vocational \& Technical College, Panjin, Liaoning, 124000 \\ a email
}

Keywords: Vocational English, Preschool Project Teaching, Career Orientation

\begin{abstract}
An important feature is the professional vocational English, that English should be linked to vocational job requirements, professional understanding of the relevant market trends. In this process, the traditional teaching methods can not provide support, can not achieve the combination of theory and practice, can not improve student learning and practical ability. Preschool Vocational English Teaching is a project-oriented teaching method focuses on practical application, to better highlight the professional characteristics of vocational English.
\end{abstract}

\section{Introduction}

According to the survey data show that the majority of vocational students basic English, the lack of intrinsic motivation to learn English (This leads to the following problems in the implementation of teacher teaching process:

Emphasize only grammar, teaching the word, to the neglect of listening, speaking, reading, writing and translation of all-round development. (2) The teaching process "re-input, light output, weight basis, light ESP". focus on the process of teaching the monotony of a one-way lecture, ignoring the language itself exchange properties. (3) Teaching English exam guide unrealistic (English exam-oriented education is not conducive to improving students' practical language skills (vocational college graduates into the community of after the application of English still showed serious suited, can not meet the market demand for talent English Higher post .2 ability 0007 year $<$ College English teaching requirements $>$ noted that reform must be followed by the market, focusing on industries and businesses foreign language skills required, strengthen employment guidance and capacity-based (with the advancement of English teaching reform in colleges, more and more researchers have been pure from the study of English language skills, English as a tool for research into how to better serve student professional, to enhance students' occupation post ability. project English teaching English for many hotspots reform vocational colleges, researchers examining the introduction of English teaching reform and post cluster fusion of English teaching content from the theoretical level, and of their projects.

\section{The Concept of Project Teaching}

Preschool Education vocational public English specialization reform objectives. Pre-professional English professional public employment reforms aimed at broadening preschool education Higher caliber graduates, in addition to all levels of society for all types of kindergartens, early childhood centers or training institutions, preschool children engaged in transporting art, early childhood care and teaching, education consulting and other professional and technical personnel Chinese language teaching or auxiliary work, will transport children in kindergarten English teachers at all levels and for all types of baby English professional training institutions, teacher help preschool teachers speak English education expertise.

Children's English teacher core job capacity. Children English baby English education teachers are fulfilling duties of professional and technical personnel, training and undergo a rigorous training, with a good work ethic and the ability to post early childhood English education. Review on the Study of "kindergarten teacher professional standards (Trial)" in conjunction with the actual research group members, I believe, baby English teacher core post ability, knowledge, experience, 
skills and attitudes that is baby English teachers will be obtained in early childhood English teaching activities or scenarios were able to complete the task of teaching English to some children the ability to post core migration and integration classes formed, which include: (1) have a higher basic English language skills: deep solid voice, intonation, vocabulary and grammar knowledge, proficiency in listening, speaking, reading, writing and translating comprehensive language skills; (2) the availability and actual use of a variety of early childhood language teaching methods: TP, pedagogy, CAI teaching method, SMILE Approach, teaching method immersion teaching, experiential teaching methods, teaching methods and other domestic and silent type forefront; (3) the ability to have some professional development: English speech, write or perform, singing English songs in English drama, etc. to expand capacity.

Project of experiential teaching mode". On the basis of existing studies, based on core early childhood English teacher post ability, relying on the pre-professional English professional public reform, put forward in line with "the requirements of Higher Education", "practical, enough" new "management, combined with solid "Teaching mode - the" project-based experience "English Teaching.

"Project-based Experience" English teaching model is an integrated, innovative teaching model, "constructivist learning theory, humanistic learning theory, pragmatic learning theory, situated learning theory, language acquisition theory" as the theoretical basis to "professional job ability" as a guide curriculum design project, using experiential teaching methods, the use of multi-stage evaluation mechanism, so that students learned in the experience "practical, applicable, enough" job knowledge and skills to meet Higher capacity for social demand for talent.

"Project-based Experience" teaching mode "preschool English teachers everyday practical work content and process" as the source of the project curriculum, teachers use teaching methods organization experiential, guide and encourage students to participate in teaching English to young children among the simulation, students access to a wealth of perceptual experience in-depth understanding of abstract rational knowledge, "in practice, experience, cognitive experience," to achieve the "truth, the real integration", "knowledge and Action."

\section{The Practical Training Standard}

On the basis of pre-professional training objectives, according to the "children of the Teaching Profession job ability" requirements to the "baby English teacher everyday practical work content and processes" for the project curriculum sources, combined with the actual research, our group will be pre-vocational professional public English professional training quality standards for targeting skills to expand from three basic aspects of the culture of language skills, children English teaching skills, career.

Basic language skills. English listening and speaking ability: the ability to understand English as a native speaker of the normal speed of speech; English pronunciation and intonation accurate; capable of Colloquial English fluently; can be in English reading, storytelling. 1.2 English reading ability: the ability to read the original English children's literature; able to read work-related information in English. 1.3 English writing skills: the ability to write in English Practical; lesson plans can be written in English; written expression in terms decent, rich vocabulary, grammatical; able to handle cultural differences properly.

Children's English teaching skills. teaching children English ability: the ability to use systems and innovative children's English teaching methods and teaching skills; English language for young children can be cultural infiltration; able to create classroom and campus environment for learning English; parents can guide the creation of family environment to learn English. 2.2 To help class teacher capacity: able to cope with foreign teachers lesson preparation; able to cope with teacher in classroom teaching; teacher can do a good job of communicating with parents bridge; can do with the kindergarten teacher training institution or a bridge. 2.3 General Teaching Teaching Abilities: Ability to develop teaching plans and summary of the work performed; able to produce a variety of teaching aids; use of modern educational technology can implement the game; can be thought of education and teaching methods used in teaching. 
Career Development skills. English drama written performance capabilities: The English version of children's literature's ability to adapt as needed; able to use English children's literature innovations capacity needed; can be different forms of children's literature in English for Teaching Children English ability ; to guide the children rehearse according to children's literature in English, the ability to show. 3.2 English songs singing ability: the ability to accurately pronounce, articulate; able to accurately grasp the song's style, with artistic appeal. English speaking ability: tone of voice standards, articulate, fluent statement, tone, intonation, sound, rhythm varied, priorities, meet cadence speech content; presentations have a strong ideological, logical, convincing and appealing, can combined with the actual, independent-minded, reflecting the contemporary college students entrepreneurial thinking spirit; good use of facial expressions, gestures and posture, tone cadence, varied, accurate and appropriately express emotion, full of emotion, skilled presentation skills , to attract the audience, there is a strong artistic appeal.

\section{The Practical Training Model}

Occupational Post group, clear teaching objectives. English teaching should be a professional basis, understand the professional market in the major group of professional positions, thereby teaching design goals. Take e - commerce as an example, the survey found that there are seven positions on the market groups: secretarial reception class, business class marketing, customer relationship management classes electricity supplier, electricity supplier sales business class, business class online advertising, web design and production category, e-commerce site maintenance and management class. For these post group, teachers can be targeted to design, make English and professional needs together, combined with the design professional needs teaching situation, to guide students familiar with the word positions within professional representation, improve their practical ability to use and multicultural exchanges and cooperation skills. This career-oriented English teaching jobs, to stimulate student interest in learning, English language learning and increase awareness of the associated job settings, so that vocational learning English more focused, targeted and directionality.

Project teaching is focusing on cooperation and exchange of companions. Project Teaching in Constructivism and Dewey "doing" put forward on the basis of theory, refers to the completion of a project by promoting the teaching and learning activities in the classroom teaching in theory and practice effectively combined. Project teaching is an open teaching mode, the teaching process has autonomy, communication and situational. Students are in the teaching process, the use of existing knowledge and experience to learn new knowledge, new knowledge for effective use of practical application, complete internalization and assimilation of knowledge in the process of applying. Project-based teaching, classroom to the students, the students are the main classroom learning, active thinking, self-construction of knowledge, teachers in the whole process only guide and help those who, through the "goal-oriented, task-driven, tell experienced union" allow students more exposure to and use of English, and continuously improve the old knowledge, construct new knowledge, initiative to complete from input to output, with learned from the process.

Introducing learning strategies to improve students' ability to learn. Learning strategy theory is a theory of education formed in the 1980s, Rubin said:. "Learning strategy is the policy language system helps learners to build self-development, these strategies can directly influence the development of .Oxford language that learning strategy is "learner to make learning easier, faster, more enjoyable, more autonomous, more effective and easier to apply to a number of specific actions taken by the new scenario." implementation of the project of pedagogy for students learning English language knowledge and enhance their language proficiency are of great help, but its implementation relies on the student's ability to learn. As a long time student vocational teachers accepted the center teaching method, students passively accept knowledge, mechanically memorize words and language syntax, mechanically imitate sentences expressed in the students in the process of thinking in a semi-closed state, the ability of independent learning skills and knowledge of sustainable development, improve the relatively weak. Therefore, vocational English in the teaching process to gradually focus on student learning Training strategy. occurred during the English 
Reformation often a misunderstanding that traditional teacher control and intervention that disproportionately affect the development of students' ability to learn, then the implementation of the project of teaching methods will give students more space to self-exploration, many teachers giving rise to a situation completely let go, resulting in a loss of students, students' learning ability is slowly developing in this process requires teachers to support and counseling. learning strategies to improve hand to give students more space for thinking, guided independent learning; on the other hand want to project design and market-related positions, display and design projects project evaluation program, the implementation of the project, the project's aspects, give specific guidance, step by step increase students' ability to learn.

The teaching process, teachers should take the initiative to practice activities to maximize the space reserved for students, since the plan, since the arrangement, since the implementation of self-management, self-monitoring. For vocational students, this is a subversive mode of learning, to fully adapt and accept the need for some time. How to set up and market preparation and actual career-related project is also an important part, there is no system of learning activities, teaching project can not be successfully implemented, the project studies also is unable to achieve good results, teachers need to do a lot of preliminary work to understand the job requirements understand students' abilities. In meeting the difficulties, but also to promote the teacher began to shift the focus of research and wider applications, explore "Work Integrated Learning", "Combination" Higher output type English teaching mode characteristics of the project.

\section{Conclusion}

In summary, the project-based teaching method is an open teaching methods, pay more attention to students' self-learning and self-discovery process. In English teaching, only with related professional job demand, market trends analysis, to be able to design a project meets the physical and mental development of students and vocational knowledge base to be able to really mobilize the students' interest and enthusiasm for learning, improve student Practical English proficiency.

\section{References}

[1] Adamson, B. China's English: A History of English in Chinese Education [M]. Hong Kong: HongKong University Press, 2004.

[2] Anderson, J. R. \& Corbett, A.T., Koedinger, K. \& Pelletier, R., Cognitive tutors: Lesson Learned. [J]. The Journal of Learning Sciences. (4), 1995.

[3] Bachman, L.F. Some reflections on situation-based language performance assessment [J]. Language Testing, 2002, 19 (4).

[4] Breen, M.P. (1984) Process syllabuses for the language classroom. In C. Brumfit (ed.) General English Syllabus Design. ELT Document 118, London: Pergamum \& British Council.

[5] Brindley, G. Situation-centred assessment in language learning: the promise and the challenge [A]. In N.Bird, P. Falvey, A. Tsui, D. Allison \& A. Mceill (Eds.). Language and Learning: Papers Presented at the Annual International Language in Education Conference (Hong Kong 1993) [C]. Hong Kong: Hong Kong Education Department, 1994.

[6] Brown, H.D. Principles of Language Learning and Teaching [M].Beijing: Foreign Language Teaching and Research Press, 2002. 